\title{
The political-economy of land acquisition and privatization of Birr and Ayehu Farms in Amhara Region, North-West Ethiopia
}

\author{
Asabu Sewenet Alamineh (10 ${ }^{1 凶}$, Getachew Fentahun Workie ${ }^{1}$ \& Nurlign Birhan Moges ${ }^{1}$
}

The recognition of commercial agricultural investment led to the expansion of large-scale farms through eviction of farmers during the Derg and Ethiopian People Revolutionary Democratic Front (EPRDF) regimes. But anti-dispossession voices and investment driven violence have frequently occurred in post-Derg Ethiopia. This study thus attempts to uncover the political-economy of land acquisition and privatization of Birr and Ayehu farms. The necessary data for the study were collected through interview, questionnaire, focused group discussion and document review. The data collected through questionnaire was analyzed using descriptive statistics and the qualitative data was analyzed thematically. The findings of the study indicated that the farms were began during the Derg regime as public enterprises, and later privatized to Ethio-Agri-CEFT in a neo-patrimonial modality with a gigantic trend of land acquisition, legal distortion and violation of landholding rights. This poor and neopatrimonial operation of farms jeopardized local livelihoods, created land use change and evoked stiff public grievance, political upheaval and polarized state-society relations. This indicated that the expansion of farms have brought lopsided development to party affiliated investors by dismantling local livelihoods. Ethio Agri-CEFT thus should respect legal frameworks and adopt inclusive developmental practices for its sustainability and success.

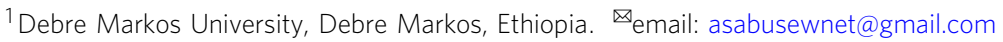




\section{Introduction}

$\mathrm{n}$ contemporary politics, land acquisition for commercial agricultural investment has become the major concern of sustainable land use and development strategy in many countries (Messerli et al., 2017). This is because the increased pressure on natural resources led to a shift in use of land from small-scale to export-driven commercial farming (Thomson, 2011). Since the 1990s, the liberalization of public policies in many countries has facilitated the establishment of agricultural investment through land acquisition (Borras and Franco, 2012). These days, commercialization of agriculture is one of the driving forces behind privatization and individualization of rights to land (Fonjong and Fokum, 2015). Especially after the triumph of neoliberalism, land acquisition for agricultural investment has been given priority by governments of both developed and developing countries to achieve food and energy security.

In Ethiopia, dispossession of land for commercial farms was introduced during the imperial regime to achieve economic growth (Rahmato, 2011). The development policy of the time was oriented with the central premises of modernization in the 1960s and early 1970s, which led to the commencement of few largescale farms (Nour, 2012). Moreover, the usurpation of power by the military regime has brought nationalization of private enterprises and establishment of state-owned commercial farms driven by socialist ideology (Meheret, 2014). The regime considered state farms as a weapon to supply food for cities and raw materials for industries despite the agrarian reform remained ineffective (Rahmato, 2011) due to political instability and economic downturn. After the downfall of $\mathrm{Derg}^{1}$, EPRDF initially focused on the intensification of smallholder agriculture as a viable means to economic growth. However, the plan failed to bring the desired goals of food security, economic growth and alleviation of poverty in the country (Glover and Jones, 2016). Consequently, a shift to commercial agricultural investment is introduced under a Plan for Accelerated and Sustained Development to End Poverty (PASDEP) to achieve national food security and development (Glover and Jones, 2016). This economic policy was aimed to develop the agriculture sector (Abbink, 2011) with unprecedented expansion of commercial farming by dispossessing small landholders (Yirsaw, 2012; Alemu, 2015).

But the dispossession of land for commercial agriculture and other purposes has become the point of contention among scholars, human right activists and the general public (Shepherd, 2013, Keeley et al., 2014, Glover and Jones, 2016). On the one hand, some argued that the expansion of commercial farming through dispossession is a return to feudalism, which devastates the wellbeing of local communities (Gebreselassie, 2006; Teshome, 2006; Rahmato, 2011; Belachew 2013). Some others contend that land dispossession for commercial farming facilitates development and food security (Ababa, 2006; Gebreselassie, 2006, Shete 2011). In this paper, however, we argue that the uncritical establishment and privatization of commercial farms affected local livelihoods and thwarted state-society relations. This is because, investors in developing countries have opted for export without feeding local communities and building the capacity of local farmers (Rahmato, 2011; Shepherd, 2013). Thus, the capitalist intrusion of land acquisition provokes unrest and political reaction against investment sites.

In this vein, Birr and Ayehu farms in Amhara National Regional State (ANRS), Ethiopia have remained the source of political grievance and turmoil. The implicit privatization, governance and exclusionary practices of farms spurred oppositions, feelings of alienation and complaints. To appraise studies about land acquisition for agricultural investment, (Araya, 2013) undertook a desktop study on the effects of large-scale agricultural investment on smallholder farming in Ethiopia. (Rahmato, 2011) studied land to investors: large-scale land transfers in Ethiopia. (Alamineh and Eneyew, 2021) also investigated the Political Economy of agricultural investment in Amhara region: a focus on flower farms in Bahir Dar Zuria district. And Addisu (2016) investigated large-scale agricultural investment and its impact on local communities: the case of Gura-Ferda district. However, these studies did not adequately investigate the problem by taking few commercial farms as a case study with data garnered from dispossessed farmers. Besides, the land for Birr and Ayehu farms was appropriated before the adoption of compensation proclamation. This indicated that the context of land eviction in Birr and Ayehu commercial farms is quite different from flower farms in Bahir Dar Zuria district, Gurra Ferda, Benishangul and Gambella regions. Moreover, the grievances and claims of the local people about the influence of Birr and Ayehu farms is neither empirically investigated nor supported by tangible evidence. In this respect, the politics of land acquisition and its local level impact is not well studied in many agricultural investments (Keeley et al., 2014). Likewise, the political-economy of domestic land acquisition in Ethiopia has remained unexplored (Cotula, 2012). The nature of land acquisition and its politics, privatization process and the influence of Birr and Ayehu farms on local livelihoods is still unclear and yet unexplored. This study thus attempted to address: (i) the politics of land acquisition, the process of privatization and its influence on local livelihoods and (ii) give voice for dispossessed farmers.

\section{Description of the study area}

Geographically, Ayehu farm is located in the current Ayehu Guagusa district, Awi administrative zone, which is $161 \mathrm{~km}$ from Bahir Dar and $475 \mathrm{~km}$ from Addis Ababa, Ethiopia. The farm was established on 46 ha of land in 1982 in the former Ankassa Gugusa district as a state-owned enterprise (Kassahun, 2018) (see Fig. 1a). Until the inception of Ayehu farm, the area was named as Embi Bita in Awi language, which means 'land of refuse'. Before it became a farm center, the area was covered by dense forests and used as an important hunting ground for the local people and the Gumz settlers. Besides, Birr farm is found at Jabi Tehnan district in West Gojjam administrative Zone, Amhara region, Ethiopia. This farm is one of the earliest commenced farm in Gojjam province during the Derg regime. It was embarked as a public enterprise in 1978 until it was sold to a private company named Ethio-Agri-CEFT in 2000. These days, the farm has two sites: Upper and lower Birr (see Fig. 1b and c, respectively). After it is privatized, the exact size of the farm is not clearly known as the company annexed more land through force.

\section{Research methods}

This study employed a mixed research approach to uncover the politics of land dispossession, privatization of Birr and Ayehu farms and their implications on local livelihoods. The use of a mixed research approach is helpful to fill the weakness of one approach with the other to better explore the research problem (Gregar, 1994; Ponce and Pagán-Maldonado, 2015; Creswell and Clark, 2017). The study districts of Jabi Tehnan and Ayehu Guagusa, destination of Birr and Ayehu farms respectively, were purposely selected. Based on proximity and influence of farms, four adjacent kebele administrations and 16 villages were chosen intentionally from the two districts proportionally. After doing so, a total of 150 sample households were selected through simple random sampling.

To substantiate the primary information, historical archives, books, journal articles, unpublished works, government reports 
a

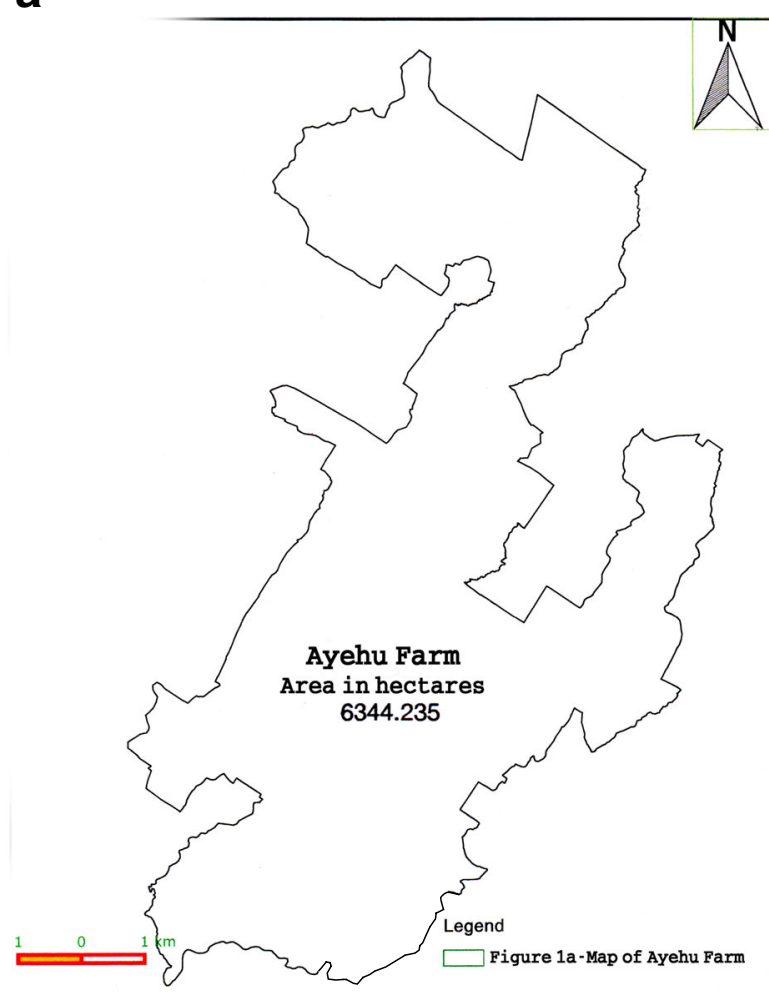

b

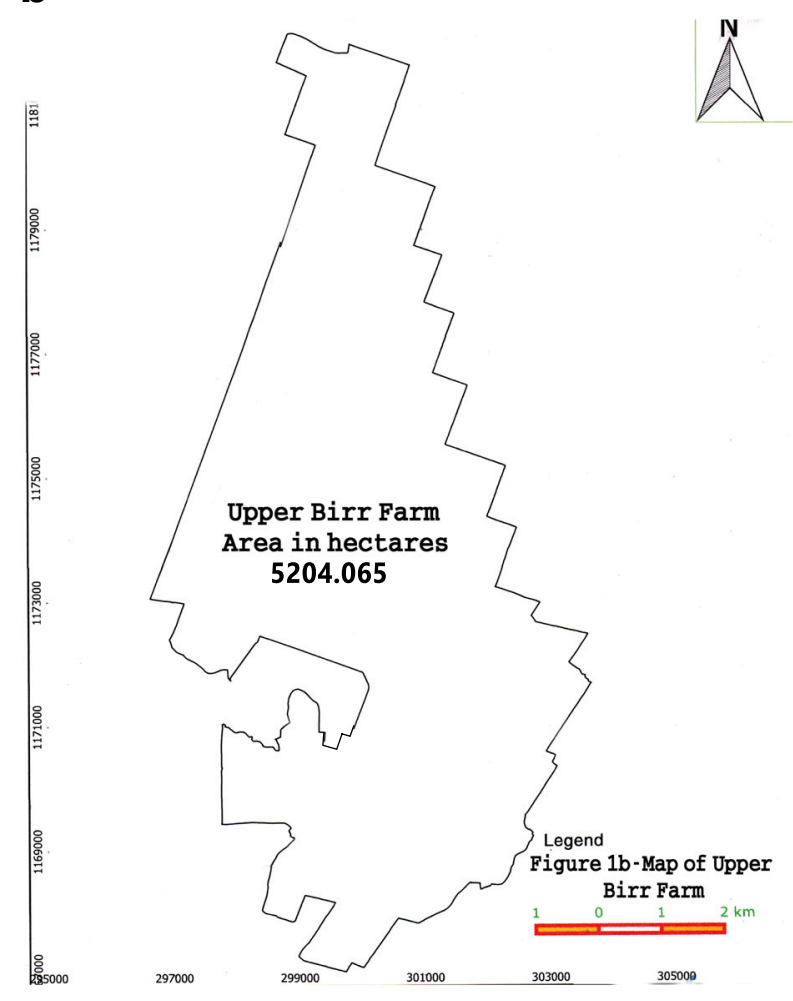

C

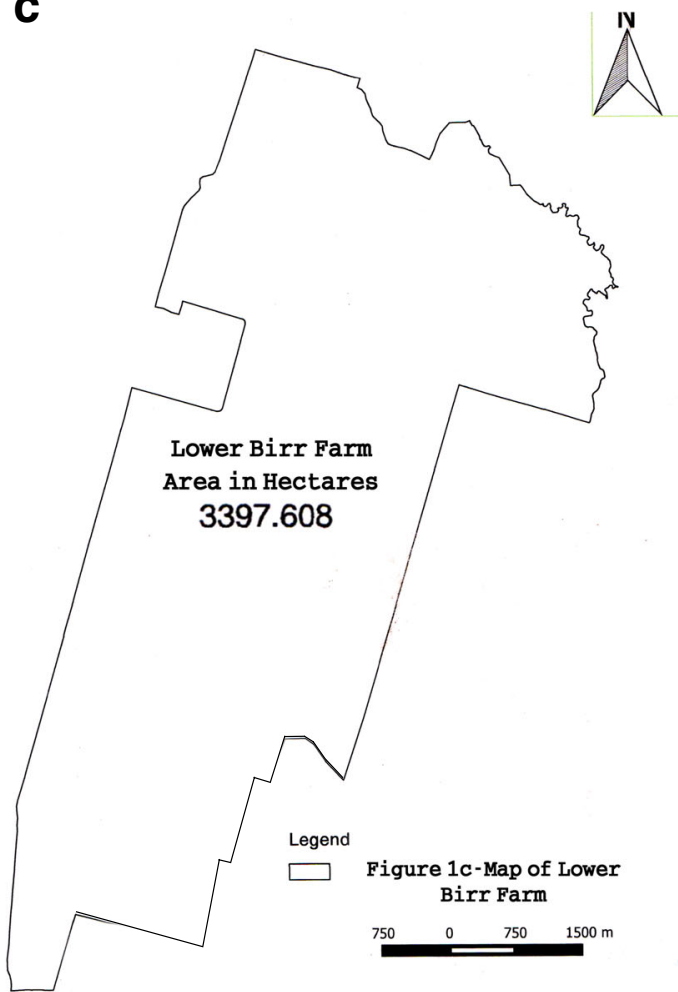

Fig. 1 Geographical map of Ayehu farm. a Refers to the geographical map of Ayehu farm found in Awi Administrative Zone of Amhara region. This farm was commenced on 46 ha of land in 1982 in the former Ankassa Gugusa district as a state-owned enterprise. $\mathbf{b}$ and $\mathbf{c}$ indicates the geographical map of upper and lower Birr farm, respectively, which is found in Jabi Tehnan district of West Gojjam zone of Amhara region. It is the earliest commenced farm in Gojjam province during the Derg regime as a public enterprise in 1978. 
Table 1 The perception of local communities about ownership of Birr and Ayehu commercial farms.

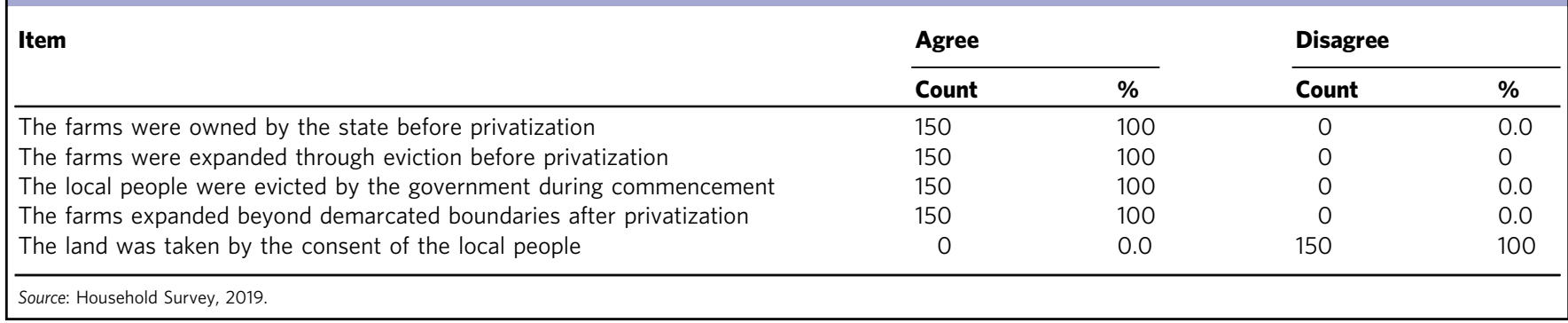

and documents of Ethio-Agri-CEFT ${ }^{2}$ were duly consulted and examined. The primary data were collected through household survey, interview and Focused Group Discussions (FGD). A household survey was conducted from 20 January to 21 May 2019 to quantify landholdings of surveyed households and the impacts of the farms on local livelihoods (Cattle, Sheep, Goat, Honey and agricultural production) and state-society relations. Key informant interview was also conducted with 24 notable local communities, government officials and scholars selected based on their knowledge, life experience and roles in the community by the help of two field assistants. And FGD was undertaken with adjacent communities to gain an insight on the issue under investigation. To this regard, four FGDs were employed with local communities by being careful to their traditions and customs. During the interview and FGD sessions, the researchers took important notes in addition to tape recording by assuring oral informed consent. After data collection, the quantitative data was presented through graphs and tables, and analyzed using descriptive statistics, whereas the qualitative data was condensed into specific patterns and analyzed thematically. Finally, the two sets of data were analyzed and integrated in accordance with the identified themes jointly.

\section{The nature of land acquisition in Birr and Ayehu farms}

After the demise of the imperial regime, Derg legislated a development paradigm insisted on non-capitalist model of development, self-reliance and new economic order of socialism (Nour, 2012).This development orientation was derived from the East European and Soviet models of dependency theory and import substitution (Rahmato, 2011) as a reaction against modernization theory and capitalism. On 4 March 1975, the regime announced an agrarian reform program known as proclamation number 31/ 1975 , which declared all rural land to be the property of the state. This land tenure policy had culminated and abolished the traditional institutions of Rist and Gult, which were the marked characteristics of the imperial regime. It further allowed state elites to dispossess land from users to plant state-owned farms, weighted and valued as key drivers of change to annihilate poverty.

Underpinned by the land reform policy and inflexible recognition of public-enterprises, Derg had displaced many peasants, and appropriated large hectares of land to launch large-scale farms. This had evidently and pervasively exposed farmers to arbitrary eviction. Because the land tenure policy had merely entitled peasants usufruct rights by underscoring agricultural collectivization, state-led economic growth and the inception of large-scale farms (Zewdie et al., 2013). Authorized by public enterprise proclamation number 20/1975, the Ministry of Natural Resources Development was empowered to commence public enterprises involved in commercial agricultural investment. To do so, the state had used its legitimate monopoly of use of force to dispossess land and commence public-owned state enterprises in various parts of the country. Consequently, the regime aggressively embarked state-owned farms and nationalized private firms to get rid of the idolatry personal gain of private investors for the development of socialist-oriented economy (Meheret, 2014; Tsegaw, 2016).

Inspired by the productive potential of Jabi Tehnan and Ayehu Gugusa districts, Birr and Ayehu farms were commenced as stateowned enterprises in 1978 and 1982 respectively. The dispossession of land for the farms was ultimately decided by a political process out-rightly driven by the ambitious motives of state elites with the denial of the rights of prior users. In this regard, the survey data confirmed that the inception of Birr and Ayehu farms were decided unilaterally by political elites without ascertaining the consent of peasants and payment of compensation (see Table 1). Not surprisingly, the top-down incipient of the farms were aided by the land tenure policy of the regime that authorized government officials to nationalize all rural lands on the one hand, and dis-empowered peasants either for compensation or land dealings, on the other hand. The land tenure policy further ignited the eviction of peasants from their landholdings to give way for state-owned farms and producer cooperatives. Using its land tenure policy as granted and uncompromised, Derg officially decried anti-dispossession politics and resistance movements against its policy reform as reactionary, resistance to change and anti-revolutionary. In return, the state elites of Derg portrayed the commencement of Birr and Ayehu farms as a pinnacle success of its progressive agrarian economic policy. This connotes that the farms were commenced by the uncompromising policy priority of Derg to indoctrinate socialist ideology.

The dispossession of land to commence Birr and Ayehu farms was initiated and run under the vanguard of the state to ensure public interest. Using its legitimate monopoly of use of force, Derg had forcefully annexed the pasture, forest and farmland of flanking communities during the commencement of Birr and Ayehu farms (see Table 1). Since the initiation of farms, local communities residing adjacent to these farms had frequently dispossessed through the use of force. Moreover, the eviction of peasants was triggered and exacerbated by the state ownership policy of land endorsed after the topple of the imperial regime. In the 1975 radical land decree, the state had entitled veto power over the use, management and allocation of land for different purposes. This excessive and unlimited authority of the state on land has increased dispossession of peasants from their pasture and farmlands for Birr and Ayehu farms.

Since the inception of the farms, land dispossession was executed in a gradual, systematic and step-by-step method without due process of law. For example, Birr farm has unprecedentedly expanded from 946 to 11,000 ha of land by dispossessing local residents in adjacent kebeles (Beyene, 2011). As indicated by respondents, the land annexed for Birr farm involves pasture, forest and farmland, which was an important livelihood base for 
neighboring communities. Likewise, Ayehu farm has expanded from 46 to 6688 ha by dispossessing flanking communities in a gradual process since its onset (Kassahun, 2018). It was unsurprising that the dispossessed local communities, in both Birr and Ayehu farms, were not compensated while they were displaced. In this regard, the land acquisition process in Ethiopia was perpetrated by denying the usufruct and customary rights of peasants since 1975 (Abbink, 2011). It is because the land tenure policy of Derg and EPRDF regimes allowed the annexation of the pasture, forest and farmland of nearby local communities for public purpose. In doing so, anti-dispossession politics and opposition against the policy of Derg in Birr and Ayehu farms was dubbed as anti-development by politicizing the grievance of peasants. Due to this reason, the land tenure policy of Derg had galvanized diminution of landholding size, tenure insecurity and inefficient utilization of land (Adal, 2002). This makes the land reform policy of Ethiopia to be a bone of contention among academicians, policy makers and the public at large.

After the overthrow of Derg, public outcry of adjacent communities in Birr and Ayehu farms has intensified further due to the unlawful dispossession of land related properties. However, the extent and scope of land dispossession has become speedy after the farms have been sold to a private investor (see Table 1) beyond the demarcated boundary. Underpinned by agricultural commercialization, the incidence of land dispossession increased globally. In India, for example, land acquisition for investment has been accelerated after the liberalization and globalization of the Indian economy (Roy, 2016). Intoxicated and salivated by the fertility and productive potential of the area, the investor has alarmingly appropriated the pasture, forest and farmland of neighboring communities' illicitly. This illegal appropriation was aided by the discretion given to the federal government overpowered by Tigray elites to manage and supervise land acquisition for large-scale commercial farms. It is deliberately done to dysfunctional the authority of regional governments over developmental projects located in their administrative hierarchies. To dominate the political-economy of the country, the federal government issued economic and political policies that allow them to lease out bulky hectares of land to party-affiliated investors without the involvement of regional governments in the land dealing process. Triggered by the unpopularity of the regime, the endless eviction of local communities for Birr and Ayehu farms has become the noteworthy concern and galvanizing force for the rise of anti-dispossession politics in Amhara region, ceteris paribus.

As indicated in Table 1, the whole surveyed households replied that Birr and Ayehu farms were state-owned enterprises managed under public enterprises proclamation number 25/1992. However, the recognition of liberalization policies widens the room for privatizing state-owned enterprises to increase productivity and efficiency. In this regard, the state elites of EPRDF regime boldly portrayed that a capitalist economy governed under the tenets of liberalism would bring productivity, progress and development. This provoked the regime to label the adoption of an unregulated economy as a weapon for poverty eradication through maximizing the productive potential of enterprises. Cognizant of such a fact, the TPLF led EPRDF regime, using its eminent domain had sold Birr and Ayehu farms to Ethio-Agri-CEFT in 2000 based on privatization of public enterprises proclamation number 146/ 1998. The political elites justified the privatization of farms as measures destined to generate revenue for developmental activities instituted by the government.

However, the farms were transferred by the unilateral decision of the EPRDF government without public deliberation, awareness of the regional government and inadequate documentation. This was because the Tigray elites had ultimately dominated the national political-economy by undermining the constitution and influenced regional governments from exercising political and economic freedom (McCracken, 2004). Besides, the sale contract of Birr and Ayehu farms and privatization treaties indicate neither the size nor time duration of the land leased out to Ethio-Agri-CEFT. Furthermore, the farms were exploited by Ethio-Agri-CEFT without undertaking a contract either with the federal or regional government for years over the issue of land usage. This is an act against legal prerequisites that obligated investors to undertake land usage agreement with concerned authorities prior to the start of actual business operation. Needless to mention, EPRDF with its affiliated companies and parastatals had been engaged in agricultural investment for the last three decades. These misdeeds of the company and corrupt nature of the regime led some to perceive that the farms were controlled by military Generals of Tigray People Liberation Front $\left(\mathrm{TPLF}^{3}\right]$, 'Bereket ${ }^{4}$ Simon' or Azeb $^{5}$ Mesfin; whereas others perceived that Sheik Mohammad Hussien Ala-ALmoudi is the owner of farms. With these complexities, the issue becomes more topical after the regional government publicized that the region does not know the owner of farms. This added fuel to the issue of ownership of Birr and Ayehu farms to be the most contentious and thorny agenda in the politics of the region.

Due to increasing public grievances, the ANRS government organized a committee in 2018 to investigate the real ownership and actual land size of the farms. But the committee found that these farms are owned by Ethio-Agri-CEFT, an enterprise shared by Mohammad International Development Research Organization Company (MIDROC) and Sheik Mohammad Hussien AlaAmoudi. In return, MIDROC is also shared by Sheik Mohammad Hussien Ala-Amoudi and his wife. Nevertheless, MIDROC is largely dubbed as an investing company tied with political elites dominating Ethiopian politics after the fall of Derg. Owing to these facts, the publicity of Ethio-Agri-CEFT, as owners of farms by the regional committee, has provoked and ignited the perception that the farms are exploited by the invisible hand of Tigray elites. It is further propagated that the issue of ownership by the company was unclear and exposed to developmental neopatrimonialism. Worded differently, activists, political elites and the general public championed that the farms have been wrongly exploited by state elites without clear guidelines of privatization as a tool to abuse entrusted authority for private gain.

Many argued that Ethiopia has been run by predatory elites, whereby resources are allocated to clients with the banner of investment. By establishing Endowment Fund for the Rehabilitation of Tigray (EFFORT), TPLF exploited the Ethiopian economy through owning parastatals engaged in agriculture, trade, cement production, textile and garment, mining and exploration, transportation, engineering, construction and finance sector (McCracken, 2004). To this end, many asserted that Birr and Ayehu farms are extracted by the invisible hand of political elites co-opted with major investors in post-1991 Ethiopia. In this regard, EFFORT and MIDROC are the major investing companies dominating Ethiopian political-economy since 1991. As a practical testimony to this, EFFORT and MIDROC were the only beneficiaries of the privatization program of state-owned enterprises in post-Derg period (Wodajo and Senbet, 2017). These companies had gained preferential treatment following the adoption of liberalization and privatization policies. State elites capture development projects that best suit their interest through the justification of public use (Arnall et al., 2013). This has made the issue of ownership in both farms to be continued as a hotspot issue in the politics of Amhara region. 
Unleashing the issue of transparency about Birr and Ayehu farms. In the post-1991 period, EPRDF had deliberately marginalized and undermined perceived rival groups to entirely dominate the political-economy of the country. To do so, it violated and under-shadowed the basic principles of the constitution by excessive intrusion on the authority of regional governments (McCracken, 2004). By adopting subsidiary laws and policies, the federal government gradually compromised the political and economic authority of regional governments granted by the constitution. Typically, a proclamation has been promulgated that grants the discretion to manage and direct large-scale commercial farms to the federal government. Based on these subsidiary laws, Birr and Ayehu farms have become under the jurisdiction of the federal government after privatization. This makes Amhara regional government incapacitated to know the exact land size of the farms. The issuances of subsidiary proclamations have restricted the authority of the regional government and it has provided the investor an avenue to surpass administrative hierarchies and to link with key federal officials.

The TPLF led EPRDF regime installed corporate corruption by wrongly extracting public assets through co-opting with stateaffiliated sympathizers (Abbink, 2011). Likewise, the increasing role of the state in land acquisition has created opportunities for the illicit graft and bribe to state elites in India (Levien, 2015). In this respect, the study participants stated that the privatization of Birr and Ayehu farms was centrally decided. It was initiated by TPLF elites and presented to the rubber-stumping parliament without proper public deliberation. The elites of EPRDF reasoned the privatization of farms as a panacea to enhance the espousal of the private sector to achieve economic growth and equitable distribution of wealth. In contrast to this justification, the Amhara state elites disclosed that the farms were sold without administrative procedures and the recognition of the regional government. The region firmly explained that the sale contract has lacked transparency in documenting the details of the privatization of farms. As indicated by the sale contract, the farms were sold for $\$ 12,500,000$ but the company paid only $\$ 9,374,600$ to the Investment Commission. It was proven by the regional committee that Ethio-Agri-CEFT has not paid $\$ 3,125,400$ to the Ethiopian government, which was either embezzled by state elites or the state-affiliated investing company. This is a practical testimony on how political elites had diverted, misallocated and misappropriated productive resources and national assets for private gain by distorting legal processes. Masking neo-liberal policies, the privatization of farms had primarily served selfperpetuating political elites and political hangers-on of the ruling regime accumulated by the efforts of peoples' sweat and blood. Similarly, the privatization policy in China created many Chinese and foreign joint ventures with plundering of public assets by state elites and their sympathizers (Le Mons Walker, 2006). It is a rent-seeking act to largely appropriate resources that brings positive returns to the rent seeker or individual than the whole public (Chakraborty, 2014). This indicates how the regime gobbles up and misappropriates national treasure and state enterprises.

The Ethiopian investment policy has granted investors both benefits and duty since the submission of investment proposals. To mention a few, investors are allowed to import tax-exempt inputs to undertake the business venture. Like the rights of investors, the government is authorized to supervise the operation of developmental projects, and legally entitled to levy land use tax from investors. Paradoxically, Ethio-Agri-CEFT failed to pay land use tax for years. This clearly marked how the investor engaged in tax fraud and embezzlement of public assets for private enrichment. The privatization process had fueled gangster capital accumulation either for the investor or unknown state elites by making the rural poor worse off. Although the operation disregards investment policies, Ethio-Agri-CEFT has imported tax-exempt inputs to maximize profit for many years. This indicated that Ethio-Agri-CEFT has used the farms as a means of wealth accumulation by co-opting power-holders through patron-client relations. The upsurge of EPRDF to power in 1991 installed corporate corruption, ultra-vires, misappropriations of national assets and pseudo-federalism (McCracken, 2004). The privatization of state-owned enterprises was undertaken in complex and distorted market-oriented policies (Deneke, 2001; Tsegaw, 2016; Wodajo and Senbet, 2017). Such uncritical liberalization policies made investors more beneficiaries at the expense of the public. In China, for instance, public assets are transferred to private entitlements under the guise of market economy using patron-client mode of functioning (Le Mons Walker, 2006).

Moreover, the study participants asserted that the regime privatized Birr and Ayehu farms without ensuring administrative accountability and transparency. The process of privatization was secret which practically enrich the economic muscle of individuals having a strong political bond with the regime. To this end, land is used as a gift to supporters of the regime to build political loyalty and installed patron-client relations in post-Derg Ethiopia (Abbink, 2011). Land acquisition for investment used as a tool by the regime to sustain the power of the party through patrimonial links (Gebresenbet, 2016). Political elites used land acquisition for investment as a magic bullet to buy the attention of supporters of the regime. Consequently, the privatizations of state-owned enterprises were used as a strategy to extend patrimonial links with their hangers-on. This is because patrimonial regimes are very strong in establishing a system that centralizes the management of economic rents for a long time via patron-client relations for political gains. In developing countries, wealthy elites used political power to extract rents from productive sectors by manipulating government decisions most favorable to their interests (Chakraborty, 2014). Likewise, the major investors in post-1991 Ethiopia are party affiliated business companies and individuals (Abbink, 2011). Evidently, MIDROC, which shares Ethio-Agri-CEFT, has been preferentially treated and benefited by the government in a way that undermines competitiveness (Wodajo and Senbet, 2017). This clearly witnessed that Birr and Ayehu farms were sold to Ethio-Agri-CEFT having a strong partnership with the ruling regime.

\section{The nature of landholding and means of livelihoods}

Land is a key natural resource helpful to address global hunger and malnutrition, accelerate agricultural productivity and achieve sustainable development goals (Mishra and Nayak, 2020). In Ethiopia, land is the most important asset and decisive natural resource that determine the basic livelihoods of rural households. It is used as a safety valve to maintain the welfare of the society on the one hand, and it is used as a weapon to earn political legitimacy and suppression of the society, on the other hand (Ganta, 2019). From antiquity, land is largely viewed as an important source of livelihood, political and economic power for a large number of people (Adal, 2002). Similarly, the contemporary understanding of livelihoods in Ethiopia prioritizes the issue of access to sufficient rural land (Tsegaye, 2016) because it is basic to the existence of people as a free and dignified human being (Garedew, 2010).

Nonetheless, land access has undergone different historical trajectories with varied political initiatives since the imperial regime (Dessalegn, 2009). Typically, following the ascendancy of EPRDF into power, land access has been used as an important strategy to maintain political power and gain political loyalties 
from the needy section of the society. Cognizant of the significance of land, the issue of land rights, land access and land distribution have occupied the epicenter of agrarian politics. Similarly, the issue of land access has become the most hotbed political and economic agenda of surveyed farming households. As the finding revealed, surveyed households had acquired sufficient farmland to earn a living and generate capital assets for their family previously. These days, however, the opportunity to access farmland was compromised due to unfolding population growth and accelerated expansion of Birr and Ayehu farms. The endless eviction of peasants' has dwindled the landholding size of flanking communities during the Derg and EPRDF regimes. Due to frequent land dispossession, 26 and 43.3 percent of sample households have possessed below 0.25 and between 0.26 up to 0.5 ha of land, respectively (see Fig. 2). And 18.7 percent of respondents held above 0.75 whereas 12 percents held a land size between 0.51 and 0.75 ha of land (see Fig. 2). These surveyed households have to sustain an average family size of 7.95 by utilizing a mean of 0.55 ha of land (see Fig. 3), which is lower than the national average (1.22 ha) (Bezu and Holden 2014). The inadequacy of farmland is, thus, one of the severe constraints to the basic livelihoods of respondents.

\section{The repercussions of land dispossession on local livelihoods} Government authorities are expected to attune the livelihood patterns of local communities before leasing farmlands for largescale agricultural investment (Shete and Rutten, 2015). But the acquisition of land by investors without careful consideration poses a serious challenge on the livelihood basis of local communities. The acquisition of land has ultimately threatens smallholder agriculture and harms local livelihoods in Ethiopia. This is because investors are profit driven and inspired to maximize their export with poor coordination to local economic development and food security (Rahmato, 2011; Aabø and Kring, 2012). The dispossession of land from peasants is associated with catastrophic and abrupt disruption of livelihoods and systematic undermining of the basis of their survival (Mishra and Nayak, 2020). Furthermore, the recognition of agricultural policies emphasizing commercial agriculture has led to dispossession of prior users in a way that declined landholding size, posed food insecurity and livelihood deprivation. To this regard, the operation of Birr and Ayehu farms and their uninterrupted expansion has undermined the livelihoods of adjacent local communities.

Incompatibility and deprivation of local livelihoods. In addition to crop cultivation, surveyed households had been engaged in Cattle, Honey, and Sheep and Goat production to supplement their livelihoods. This was because, the pasture and forestland of adjacent communities was not annexed and fully utilized by the farms until privatization. Gradually, farming households were coerced to reduce the size of Cattle, Honey, Sheep and Goat production due to the swift expansion of farms around the homestead of flanking communities (see Table 2). The reduction of Cattle herd size has led to the decline of milk cows on 97.3 percent of surveyed farming households (see Table 2). This contributed to the radical decline of mean Cattle possession of surveyed households from 12.65 to 1.906 for the last 15 years (see Fig. 4). Additionally, the engagement of households in honey production was declined from 78.7 to 14 percent recently (see Table 2) due to the use of excessive pesticides and chemicals by Ethio-Agri-CEFT. Cognizant of such a fact, the mean Bee Hive possession has declined from 6.906 to 0.55 for the last 15 years (see Fig. 4). Moreover, Sheep and Goat production was largely practiced by adjacent communities to ameliorate livelihoods and diversify incomes. However, the number of households involved in Sheep and Goat production has declined from 75.3 to 12 percent today. And almost 88 percent of households abandoned rearing of Sheeps and Goats caused by shortage of pasture land (see Table 3). This in turn declined the average Sheep and Goat possessions from 6.82 to 0.64 because of farms' (see Fig. 4). The burning of the byproducts of crops, excessive use of pesticides and annexation of the pasture and forestland of adjacent communities by Ethio-Agri-CEFT all in all undermined Cattle, Honey, Goat and Sheep production of local residents. This clearly indicated that the operation of farms brought incompatibility and deprivation of the livelihoods of local communities.

Landlessness, shortage of farmland and land use change. The advent of large-scale commercial farms has constrained the opportunity and condition of land access in Ethiopia (Tsegaye, 2016). In this vein, the endless land enclosure by Birr and Ayehu farms has aggravated landlessness, shortage of farmland and land use change on flanking communities. As the finding revealed, the inception of Birr and Ayehu farms exacerbated the problem of landlessness and shortage of farmland in the area. This is because, the incipient of farms engendered dispossession of pasture, forest and farmland of prior users. During the past decades, periodic land redistribution has been used as a means to address land shortage and landlessness in the country (Adal, 2002; Derseh and Belay, 2019). However, the opportunity of land redistribution to landless youths and land stressed households became difficult due to the endless annexation of the pasture, vacant and forestland of local communities by the farms. In this respect, the Amhara region has officially banned land redistribution with the exception of irrigated land and other few scenarios in its revised rural land administration and use determination proclamation number 252/ 2017.

Despite land shortage and legal restrictions, the regional government did not undertake land redistribution to landless rural poor's in post-1991. As a result, landlessness and shortage of farmland continued as marker of public uproar in adjacent kebles' of the two farms. Before the privatization of Birr and Ayehu farms, there had been great opportunities to access farmland either for share cropping or renting. Currently, however, there has been severe competition among local communities for renting and share cropping caused by rapid population growth and shortage of farmland. Furthermore, the fast growth of the local population has aggravated and complicated the competition to access land through various channels. As shown in graph 4 , the mean farmland size of surveyed households has declined from 3.69 to 0.55 ha over the last 15 years. The reduction of farmland is caused by the appropriation of land by the farms and sharing to elder children. For housing and farming purposes, surveyed households have been coerced to share their farmland to children's forming families as a means of livelihood. This contributes to diminution of farmland size, landlessness and land use change in the study area.

Reduction of crop production and food insecurity. In the agrarian economy of Ethiopia, crop production is the mainstay of the economy and source of survival for its people (Abbink, 2011). But the rapid population growth and commercial agricultural intensification led to diminution of farmlands for crop cultivation to meet food security. Most importantly, the expansion of private and state-owned commercial farms ended in the dispossession of huge farmlands from a significant number of peasants in a way that brings land use change from crop cultivation for food security to production of high cash crops for commercial purposes (Tsegaye, 2016). It is obvious that crop cultivation is the major source of livelihood for surveyed households, but the 


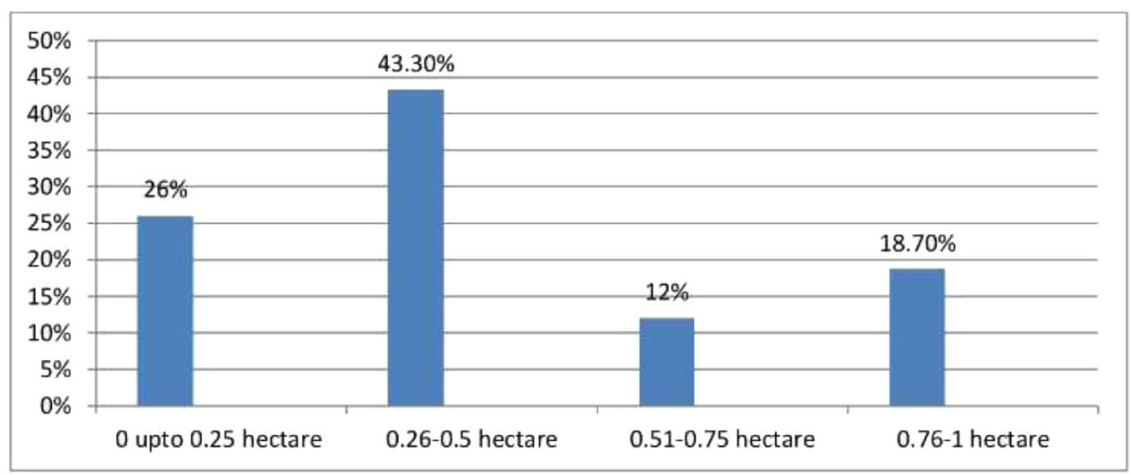

Source, household survey 2019

Fig. 2 Surveyed households' farmland holding size around Birr and Ayehu farms. Figure basically indicates the land size held by surveyed households in the study area generated from the field survey of study participants. Among the total respondents, about 26, 43.3, 12 and 18.7 percent of respondents held below 0.25 , between 0.26 up to $0.5,0.51$ up to 0.75 and above 0.75 ha of land, respectively.

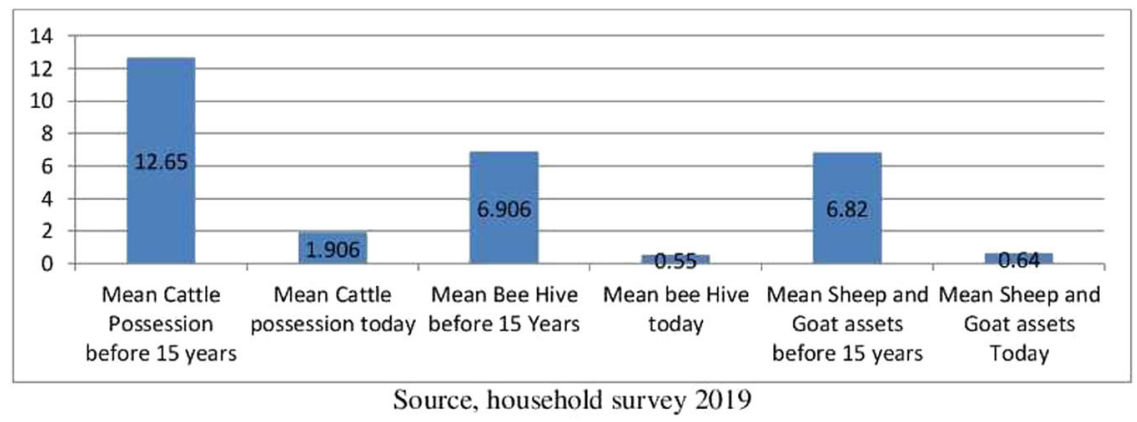

Fig. 3 Comparison of current mean landholding size of sample households before $\mathbf{1 5}$ years. Figure also compared the current mean landholding size of surveyed households with the last 15 years. The land size held by farming households was getting scanty and scanty by the illicit horizontal expansion of farms.

commencement of farms has reduced the extent of agricultural yields. Practically, the mean crop production of respondents has been reduced from 68.95 to 12.06 quintals for the last 15 years (see Fig. 5) due to landlessness, unlawful annexation of farmland by the investor, shortage of farmland and land use change. The agricultural status of farmers is determined by the amount of landholding in India (Roy, 2016). Similarly, the diminution of landholding brings reduction of agricultural production and income generation in Ethiopia (Desalegn, 2013). It is further noted that small landholding size is a major factor that constrains peasants' income and food security due to reduction of agricultural production (Nega et al., 2003). This indicates that Birr and Ayehu commercial farms have brought reduction of crop production due to endless land enclosures of flanking communities, ceteris paribus.

\section{The political ramifications of land dispossession in Birr and Ayehu Farms}

The triumph of liberalism has aggrandized the extent of land dispossession for commercial agricultural plantation, real estate investment, manufacturing industries and special economic zones in different states. In Ethiopia, the unrestricted land enclosure by state-owned enterprises and private investors aggravated the politics of land over the past few decades (Tsegaye, 2016). The land tenure policy enforced since the ascendance of the military regime granted the state veto power over the allocation, management and distribution of land. Cognizant of the development policy of the regime and demand for economic growth, land acquisition for commercial farming, hydraulic dams, real estate and infrastructural development has been accelerated alarmingly in post-1991 Ethiopia (Rahmato, 2011). However, dispossession of land generates friction, counter discourses and become foci of conflict and political antagonism (Abbink, 2011). Similarly, the inception of Birr and Ayehu farms have invoked sustaining public uproar caused by the aggressive land acquisition and its devastating social, political and economic troubles inflicting on adjoining local communities. These unfriendly practices of farms and the grave dispossession by Ethio-Agri-CEFT have engendered public grievances on bordering communities (see Table 3). But opposition against land acquisition by the community, activists and political elites was viewed as anti-development and antipeace by the EPRDF regime.

The impact of farms on state-society relations. For long, Ethiopian politics has been marked by persistent struggle for land rights and political representation. This is because state-society relations primarily focus on power relations between the state and the society over resource allocation and political decision making (Migdal, 2001; Bekele et al., 2016). The issues of land ownership and land rights have been at the forefront of politico-economic fabrics of the state in general and state-society relations in particular. For example, the question of 'land to the tiller', advocated by Ethiopian students in the 1960s was the major galvanizing force for the 1974 revolution. Since its usurpation of power, Derg has adopted state ownership of land that invoked extended land dispossession for state led development, commercial farming and other purposes. Likewise, Birr and Ayehu commercial farms are 
Table 2 The perception of respondents on the impacts of Birr and Ayehu farms on livestock production.

\begin{tabular}{|c|c|c|c|c|}
\hline \multirow[t]{2}{*}{ Item } & \multicolumn{2}{|l|}{ Agree } & \multicolumn{2}{|c|}{ Disagree } \\
\hline & Count & $\%$ & Count & $\%$ \\
\hline The expansion of farms brings the decline cattle herd size & 150 & 100 & 0 & 0.0 \\
\hline Milk cows have reduced since the privatization of farms & 146 & 97.3 & 4 & 2.7 \\
\hline Households were engaged in honey production prior to farms & 118 & 78.7 & 32 & 21.3 \\
\hline Farming households are involved in honey production today & 21 & 14 & 129 & 86 \\
\hline Households reared Sheeps and Goats prior to farms & 113 & 75.3 & 37 & 24.7 \\
\hline Sheeps and Goats are reduced by the expansion of farms & 150 & 100 & 0 & 0.0 \\
\hline Household heads have possessed Sheeps and Goats currently & 18 & 12 & 132 & 88 \\
\hline Number of beehives decreased since the farms privatized & 150 & 100 & 0 & 0.0 \\
\hline Production of honey per year reduced due to farms expansion & 150 & 100 & 0 & 0.0 \\
\hline
\end{tabular}

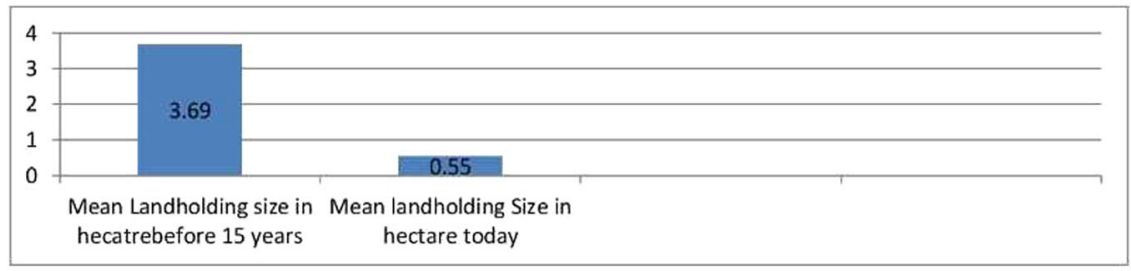

Source, household survey 2019

Fig. 4 Comparison of current mean Cattle, Bee Hive, and Sheep and Goat assets of households before $\mathbf{1 5}$ years. Figure makes a comparison of the current mean Cattle, Bee Hive, Sheep and Goat assets owned by surveyed households before the last 10 years. It tried to show the influence of farms on the livelihoods of flanking communities.

Table 3 The perception of respondents about the effect of farms on government-society relations.

\begin{tabular}{llll} 
Items & Agree count & \% & Disagree count \\
\hline State-society relations has been affected by Birr and Ayehu farms & 150 & 100 & 0 \\
The farms have created local grievance & 150 & 100 & 0 \\
Conflict occurred between local communities and the investor & 150 & 100 & 0 \\
The community distrust the government due to farms & 150 & 100 & 0 \\
Farms have made households' attitude negative to the government & 150 & 100 & 0.0 \\
\hline Source: Household Survey 2019. & & 0.0 \\
\hline
\end{tabular}

commenced by annexing pasture, forest and farmlands of adjacent communities under the aegis of socialism.

Following the privatization of these farms, there has been myriad of interest and lust for monopoly of land by Ethio-AgriCEFT. Accordingly, the company has organized an informal security force of its own to annex vacant land and to sustain looting of resources by terrorizing and destabilizing local communities. Bypassing formal legal procedures, such security forces of the company kidnaped, tortured and imprisoned local residents, employees and government officials that oppose unlawful expansion, claim rights and expose misdeeds. To put an example, the former chairperson of Social Affairs of Jabi Tehnan District was kidnaped and imprisoned by the security force of Ethio-Agri-CEFT for a day. The illicit expansions and malefaction of these farms are supported by government hierarchies both at regional and federal level. Political elites representing and ruling the society are either incapacitated to control illegal dispossession of local communities by Ethio-AgriCEFT or gave fell ear for community's oppressed voices. This is because in states having weak protection of property rights, the rich can purchase arms, political power and bureaucracy for further exploitation of national treasure (Chakraborty, 2014).
Similarly, Ethio-Agri-CEFT has manipulated and used government bureaucracies to sustain exploitation, misappropriate national assets and protect its businesses from demolition.

Ethio-Agri-CEFT created fear, psychological trauma and social insecurity in adjacent communities. Due to patrimonial linkage, regional, zonal and district government authorities ignored and politicized the claims and complaints of flanking communities. On the one hand, the unlawful eviction of land users and residents perpetuated livelihood deprivation, exploitation, destabilization, denial of land rights and social alienation. This in turn deepens political dissatisfaction, grievances and lack of trust towards the government. And, as Mierina (2014) noted, the presence of distrust between the government and society leads to antagonistic state-society relations. The survey of our study firmly confirmed the presence of antagonistic state-society relations due to Ethio-Agri-CEFT's wrongdoing and inability of state elites to safeguard the wellbeing of local communities (see Table 3). Because of the increased exclusionary practices and illicit expansions, the farms have been seen as the revived form of oppressive tenant-lord relations of feudalism. Such unfriendly relations resulted in demonstration, destruction of government institutions, banning of transportation of agricultural products 


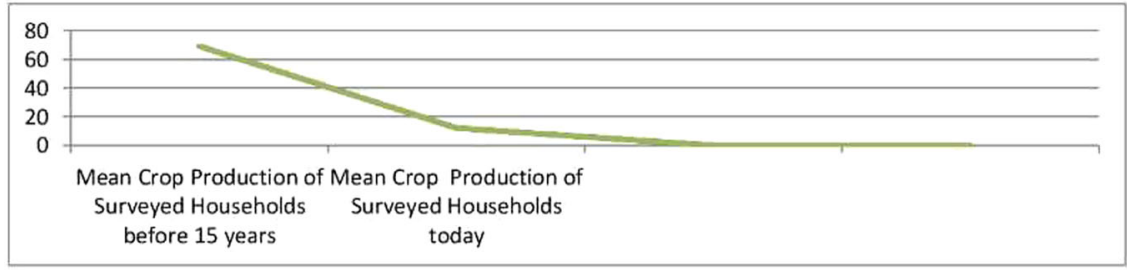

Source, household survey 2019

Fig. 5 Comparison of current mean crop production with before 15 years. Figure tried to show the current mean variation of surveyed households' agricultural production with the last 15 years. It stipulated the influence of farms on the agricultural production of respondents.

and burning of investment sites particularly in Birr farm. The illegal expansion of farms thus undermined the wellbeing and livelihood of flanking societies, which significantly impacted the nature of state-society relations.

The privatization of Birr and Ayehu farms has brought land dispossession, repression and incompatibility of livelihoods. Like colonial masters, Ethio-Agri-CEFT fully entered into resource scramble. The company relentlessly plundered and gobbled up trees grown naturally or artificially on pasture, forest and farmland of flanking communities without having any license. The greedy extraction and looting of resources situated in Birr and Ayehu farms was done through manipulation and purchase of government bureaucracies and weapons. These malpractices of the company compelled local communities to label the farms as 'junior Mekelle', whereby resources were exploited by a few mafias co-opted with state elites. State elites working at different administrative hierarchies neither regulate the illicit and speedy expansion of farms nor control malpractices. Rather than responding to the claims and rights of the locals, the regional government blackmailed questions and grievances as political issues triggered by anti-peace forces. Finally, the government's over-silence to company's misconducts led to antagonistic state-society relations.

Because of the regional government's inability to safeguard the rights of people, local residents perceived Amhara National Democratic Movement (ANDM) as a manservant and delegate of TPLF. The leaders of ANDM are further seen as demagogue politicians who deserve neither ability nor morality to represent adjacent communities. Local communities developed such labeling with the feeling that ANDM is deliberately formed to denounce the formation of genuine political parties by the Amhara ethnic group. Political elites further argued that the creation of ANDM was inspired by political sabotage and trickery of TPLF elites to leave Amhara without a genuine representative in an ethnically organized polity. Due to its very nature, ANDM became a Trojan horse, opted and prioritized to secure long-term political office than promoting the wellbeing of the people it represented. Not surprisingly, the dispossession of the locals, exploitation of employees, misappropriation and looting of resources in Birr and Ayehu farms has got legal protection by administrative hierarchies of ANDM. These misdeeds of EthioAgri-CEFT have engendered political dissatisfaction, inimical attitude and loss of trust to the government. The survey data inferred that the whole farming households have developed mistrust, suspicion, and hostility to the government (see Table 3). This is the reason Rahmato (2011) opined that the absence of public deliberation on land dispossession for public and privateowned commercial agricultural investment causes popular grievances and violence. Hence, its unresponsiveness to ceaseless questions and claims has made the government unpleasant in the eyes of peasants.

Another impact the farms had on state-society relations is the occurrence of turbulence, arrest and death. In principle, agricultural investments need to be inclusive to share benefits to evictees, investors, government and local communities (Yirsaw, 2012). Nonetheless, unfair distributions and appropriation of resources marked by economic vulnerability and deprivation of livelihoods aggravated grievances and demolishment of investment projects by the excluded section of the society (Guo, 2001; Collier and Hoeffler, 2004, McCandless and Karbo, 2011). In other words, unclear land acquisition, exclusionary development and feeling of marginalization trigger violence and antiinvestment riots. In India, for example, the expropriation of land for private and public investment by the state using its eminent domain has generated acute agrarian uproar (Levien, 2013). The exclusionary practices of development projects have invoked opposition and demolishment in Bahir Dar Zuria district (Asabu, 2018), BakoTibee (Rahmato 2011), Legedembi gold mining and Gojeb kebele Bonga. Similarly, the devastative impact of Birr and Ayehu farms on the economic wellbeing of adjacent communities and employees set off conflict of interests. Our survey affirmed the occurrence of political turbulence and violence at Birr and Ayehu commercial farms (see Table 3) because of unending eviction, cumulative grievances and lopsided development practices.

Considering the legal duty and moral burden of the state, adjacent communities submitted petitions to the respective district administrations in August 2018 to clarify the issue of farms. However, state elites did not promptly respond to the complaints, which ignited the youth to enter into violent activities especially in Birr farm. The failure to provide adequate and timely information to public questions added fuel on the already volatile politics of farms. The government wanted to maintain the status quo, however using social media the issue of the farms became more acute. Indeed, the operations of farms have instilled injustice, incompatibility and deprivation of livelihoods. The lack of clarity about Birr and Ayehu farms created more grievance, resentment and fierce opposition. Instead of addressing growing complaints, the government reacted violently by denying basic concerns and claims. Of course, EPRDF is intolerant towards opposite voices of land acquisition for commercial agricultural investment (Abbink, 2011). Finally, violent conflicts and political chaos erupted in Jabi Tehnan and Ayehu Guagusa districts and widened its horizon to other places. More specifically, the violence of Birr farm was more devastative and risky, resulting in mass imprisonment, robbing and destruction of crops, physical injury and death. Similar anti-dispossessions against the government and investors have occurred by project affected communities in India (Roy, 2016). Unclear land dispossession and lack of consent causes local resistance and political opposition against investment sites (Posluschny-Treuner, 2012; Smalley, 2014). This is because weak governance of agricultural investments and land resources brings a myriad of risks on prior users. Thus, investments that lack clarity and sense of responsibility to local communities are prone to opposition and destruction. 


\section{Conclusion}

The EPRDF regime inspired by neo-liberal policy had promoted speedy capitalist led agricultural investment as a panacea to eradicate poverty. To enthusiastically praise the role of liberalization, political elites acclaimed the commencement and expansion of large-scale commercial farms as the most efficient means of ensuring food security and national development by medicating the problem of smallholder agriculture. This paradigm shift transformed land allocation from small to large-scale commercial farming through an aggressive eviction of local communities from their holdings without legal procedures. The dispossession of prior users is aided by the land tenure policy of the country endorsed since the demise of the imperial regime. In post-Derg Ethiopia, land is jointly owned by the state and the public despite the former having veto power in land use, allocation and management for the expansion of agricultural investment and other purposes. This unfolded the number of both domestic and foreign investors radically by denying the usufruct rights of farmers with a justification of better use of land and maximizing public interest. By and large, EPRDF issued proclamations that allowed privatization of state-owned enterprises and the inception of large-scale farms driven by market led policy of development. However, the fierce outspread of large-scale commercial farming through land grabbing under market led policy framework has restored and reinforced class inequality. This neo-liberal move created classes marked by the domination of few gangster capitalists against displaced and disgusted majority agrarian communities.

In this regard, the state elites of EPRDF had sold Birr and Ayehu farms to Ethio-Agri CEFT by unclear sale contract undertaken with Ethiopian Privatization Agency underpinned by the tenets of market fundamentalism. However, the privatization process was perpetrated in secret, and exposed to rent seeking without full details on the length of time and land size leased out to the investor. The company had extracted the assets of the public without being contracted either with the federal or regional government until June 2019 with vigorous dispossession of peasants. Initially, the land acquisition of farms was reasoned by Derg and EPRDF elites to achieve development and to meet food security. Furthermore, the state elites of EPRDF justified the dispossession of land and privatization of farms for development and to enhance the espousal of the private sector in the economy. But the expansions of farms have remained gigantic and oppressive to the surrounding communities since privatization. Prior to the sale of farms, local communities had been benefited through sharing of experience and use of byproducts of crops and grasses for various purposes. Contrastingly, Ethio-Agri CEFT has become a more profit oriented enterprise in a way that poses economic, social and political threats to local communities. By and large, the operation of Ethio-Agri-CEFT created incompatibility of livelihoods, caused landlessness, land shortage, land use change and reduction of agricultural production through distortion of the freedoms and land rights of prior users by its security forces. This exploitative and oppressive practice of farms begets public grievances and makes government-society relations flawed and bad mannered. In return, the faulty government-society relations and concentrated grievance brought chaos, conflict and deterioration of government legitimacy. Cognizant of these facts, the farms of Birr and Ayehu are considered as oppressive as feudalism and the revived form of tenant-lord oppression by the people of Amhara region. Hence, the company should be governed by the proclamations, policies and rules of ANRS to ensure its legality in a way that extends public interest.

\section{Data availability}

All data generated or analyzed during this study are included in this article.

Received: 21 September 2020; Accepted: 27 October 2021; Published online: 23 November 2021

\section{Notes}

1 Derg was a regime assumed political power in Ethiopia through force by cut-off the imperial regime in 1974. It was a committee that comprises 120 members with supreme power, brainwashed by Marxist-Leninist socialist ideology. The regime ruled Ethiopia by mere decrees and proclamations without having a constitution until 1987 until it was replaced by the Ethiopian People Revolutionary Democratic Front (EPRDF) in 1991 through bloodshed armed struggle.

2 Ethio-Agri-CEFT PLC is a private investing company established in 1997. It is founded as one of Mohammad International Development Research Organization Companies group companies engaged in Agro-industry. The company has produced highland grown coffee and tea, spices and food crops, flowers, herbal medicinal and biopesticide plants. It is a dominant business venture and its major investment projects have located in nine sites of Ethiopia.

3 TPLF military Generals are long serving military personnel's worked dedicatedly during TPLF's military struggle against the military regime. After the topple of Derg, the military Generals of TPLF were working day and night as guardians of TPLF led EPRDF regime to ensure the domination of the party on Ethiopian politics.

4 Bereket Simon was one of the leading and influential politician dominated Ethiopian politics in the period between 1991 and 2018 within Amhara National Democratic Movement (ANDM) and EPRDF. Following the coming of Abiy to the premiership in 2018, Bereket Simon has put in jail on the malpractices and corruption committed during his leadership.

5 Azeb Mesfin was the leading politician dominated Ethiopian politics since the ascendance of EPRDF to power in 1991. She was the wife of the former influential prime minister of Meles Zenawi and suspected as one of the leading individual controlled EFFORT for several years by being chairman of its board. And she was labeled as one of a well-known state elite involved in misappropriations of public assets for private regarding until the death of Meles Zenawi.

\section{References}

Aabø E, Kring T (2012) The political economy of large-scale agricultural land acquisitions: implications for food security and livelihoods/employment creation in rural Mozambique. United Nations Development Programme Working Paper 4. pp. 1-61

Ababa A (2006) Ethiopia: building on progress a Plan for Accelerated and Sus tained Development to End Poverty (PASDEP). Ministry of Finance and Economic Development (MoFED)

Abbink J (2011) 'Land to the foreigners': economic, legal, and socio-cultural aspects of new land acquisition schemes in Ethiopia. J Contemp Afr Stud 29(4):513-535

Adal Y (2002) Review of landholding systems and policies in Ethiopia under the different regimes. Ethiopian Economic policy Research Institute working paper, Addis Ababa

Addisu G (2016) Large scale agricultural investment and its impact on local communities: the case of Gura Ferda Woreda. MA Theses, Addiss Ababa University, Ethiopia

Alamineh AS, Eneyew BG (2021) Unleashing the political economy of land expropriation in Ethiopia, beyond the rhetoric: flower farms' in Amhara Region in focus. Bandung 8(1):102-123

Alemu GT (2015) Land expropriation and compensation payment in Ethiopia: review. J Econ Sustain Dev 6(13):93-97

Araya M (2013) Effects of large-scale agricultural investments on small holder farming in Sub-Saharan Africa (Case study: Ethiopia)

Arnall A, Thomas DS, Twyman C, Liverman D (2013) NGOs, elite capture and community-driven development: perspectives in rural Mozambique. J Mod Afr Stud 51(2):305-330

Asabu S (2018) The nature of land expropriation and compensation in Amhara National Regional State; a focus in Bahir Dar Zuria Woreda. International Journal of Political Science and Development. 6(7):xxx-xxx

Bekele YW, Kjosavik DJ, Shanmugaratnam N (2016) State-society relations in Ethiopia: a political-economy perspective of the Post-1991 order. Soc Sci $5(3): 48$

Belachew Y (2013) Expropriation, valuation and compensation in Ethiopia. Doctoral Theses, Royal Institute of Technology, Stockholm, Sweden

Beyene C (2011) A history of Javi Tehnan Woreda (West Gojjam), 1941-1991. MA Thesis, AAU, Ethiopia 
Bezu S, Holden S (2014) Are rural youth in Ethiopia abandoning agriculture? World Dev 64:259-272

Borras Jr SM, Franco JC (2012) Global land grabbing and trajectories of agrarian change: a preliminary analysis. J Agrar Change 12(1):34-59

Ckakraborty S (2014) Rent-seeking. Article in IMF staff papers.April 2006 https:// doi.org/10.5089/9781451860627.001 Source: RePEc https://www.researchgate.net/ publication/5222095_Rent_Seeking

Collier P, Hoeffler A (2004) Greed and grievance in civil war. Oxford Econ Pap 56(4):563-595

Cotula L (2012) The international political economy of the global land rush: a critical appraisal of trends, scale, geography and drivers. J Peasant Stud 39(34):649-680. https://doi.org/10.1080/03066150.2012.674940

Creswell JW, Clark VLP (2017) Designing and conducting mixed methods research. Sage Publications

Deneke S (2001) Private sector development in Ethiopia. Center for African Development Policy Research

Derseh E, Belay M (2019) Push factors, household support and effects of communal land distribution in Gozamin District, Ethiopia. Ethiop J Soc Sci 5:1

Desalegn K (2013) The socio-economic and environmental impacts of large scale (agricultural) land acquisitions on local livelihoods: a case study of Bako Tibee Woreda. MA Theses, University of Oslo, Blindern, Norway

Dessalegn R (2009) The Peasant and the State: studies in agrarian change in Ethiopia 1950s-2000s. Addis Ababa University Press, Addis Ababa

Fonjong LN, Fokum VY (2015) Rethinking the water dimension of large scale land acquisitions in sub-Saharan Africa. J Afr Stud Dev 7(4):112-120

Ganta BG (2019) Access to rural land rights in the post-1991 Ethiopia: unconstitutional policy shift. J Land Rural Studs 7(1):1-22

Garedew E (2010) Land-use and land-cover dynamics and rural livelihood perspectives, in the semi-arid areas of Central Rift Valley of Ethiopia. Thesis, Faculty of Forest Sciences, Department of Forest Resource Management Umeå

Gebreselassie S (2006) Intensification of smallholder agriculture in Ethiopia: options and scenarios. Future Agricultures Consortium Meeting at the Institute of Development Studies

Gebresenbet F (2016) Land acquisitions, the politics of dispossession, and stateremaking in Gambella, western Ethiopia. Afr Spect 51(1):5-28

Glover S, Jones S (2016) Can commercial farming promote rural dynamism in subSaharan Africa? World Dev 114:110-121

Gregar J (1994) Research design (Qualitative, Quantitative And Mixed Methods Approaches). SAGE Publications. p. 228

Guo X (2001) Land expropriation and rural conflicts in China. China Q 166:422-439

Kassahun D (2018) A History of Ayehu farm. (MA Thesis, Bahir Dar University, Ethiopia)

Keeley J, I. I. f. Environment and Development (2014) Large-scale land deals in Ethiopia: scale, trends, features and outcomes to date, International Institute for Environment and Development (IIED)

Levien M (2013) The politics of dispossession: "theorizing India's land wars". Politics Soc 41(3):351-394

Levien M (2015) From primitive accumulation to regimes of dispossession: six theses on India's land question. Econ Political Wkly 146-157

McCandless E, Karbo T (2011) Peace, conflict, and development in Africa: a reader. University of Peace (UPEACE), San Jose, Costa Rica

McCracken MJ (2004) Abusing self-determination and democracy: how the TPLF is looting Ethiopia. Case W Res J Int 36:183

Meheret T (2014) The concept and characteristics of public enterprises in Ethiopia: an overview. Mizan Law Rev 8(2):333-370

Messerli P, Oberlack C, Tejada L, Rist S, Giger M (2017) Sustainable livelihoods in the global land rush? Archetypes of livelihood vulnerability and sustainability potentials. Keynote presentation

Mierina I (2014) Political alienation and government-society relations in postcommunist countries. Pol Sociol Rev 185(1):3-24

Migdal JS (2001) State in society: studying how states and societies transform and constitute one another. Cambridge University Press

Mishra D, Nayak P (2020) Land and livelihoods in neo-liberal India. Springer Nature Pte Ltd

Le Mons Walker K (2006) 'Gangster capitalism'and peasant protest in China: the last twenty years. J Peasant Stud 33(1):1-33

Nega B, Adenew B, Gebre Sellasie S (2003) Current land policy issues in Ethiopia. Land Reform Land Settl Coop 11(3):103-124

Nour E (2012) The investment promotion and environment protection balance in Ethiopia's Floriculture: the legal regime and global value chain. $\mathrm{PhD}$ thesis, University of Warwick

Ponce OA, Pagán-Maldonado N (2015) Mixed methods research in education: Capturing the complexity of the profession. Int J Educ Excell 1(1):111-135

Posluschny-Treuner M (2012) International large-scale land acquisitions in Ethiopia: the key to trigger agricultural modernization, development and poverty reduction? In: Proceedings of the 4th ECPR graduate conference. Jacobs University, Bremen
Roy A (2016) Land acquisition and rural transformation: a case study from West Bengal. Chin Sociol Dialogue 1(1):32-47

Shepherd B (2013) GCC states' land investments abroad: the case of Ethiopia. CIRS Summary Report

Shete M, Rutten M (2015) Impacts of large-scale farming on local communities' food security and income levels-empirical evidence from Oromia Region, Ethiopia. Land Use policy 47:282-292

Shete M (2011) Implications of land deals to livelihood security and natural resource management in Benshanguel Gumuz Regional State, Ethiopia. A paper presented at the international conference on "Global Land Grabbing", University of Sussex. April 6-8, 2011.Brighten, UK

Smalley R (2014) Large-scale commercial agriculture in Africa: lessons from the past. Institute for Poverty, Land and Agrarian Studies

Teshome A (2006) Agriculture, growth and poverty reduction in Ethiopia: policy processes around the new PRSP (PASDEP). A paper for the Future Agricultures Consortium Workshop. Institute of Development Studies, University of Sussex, UK, Citeseer

Thomson KJ (2011) Rising global interest in farmland: can it yield sustainable and equitable benefits? In: Deininger K, Byerlee D with Lindsay J, Norton A, Selod H and Stickler M (eds) The World Bank, Washington, p. 214. £25.00. ISBN 978-0-8213-8591-3. Exp Agric 47(4):730-730

Tsegaw E (2016) The legal status of state-owned share companies in Ethiopia. Beijing Law Rev 7:12

Tsegaye M (2016) The political economy of the land-livelihoods nexus in an era of ecological change and the global land rush: access to land, land conflict and large-scale land xxv, acquisitions in Ethiopia. Doctoral dissertation, Erasmus University Rotterdam, Institute of Social Studies

Wodajo T, Senbet D (2017) Does privatization improve productivity? Empirical evidence from Ethiopia. Int J Afr Dev 4(2):3

Yirsaw B (2012) Expropriation, valuation and compensation practice in Amhara National Regional State (ANRS) - the case of two cities (Bahir-Dar and Gonder). Nordic J Surv Real Estate Res 9:1

Zewdie Y, Teshome A, Berhanu K (2013) Drivers' of success for CAADP implementation Ethiopia, case study

\section{Acknowledgements}

We would also like to thank all the study participants for their voluntary participation We would like to thank Kidanu Atinafu and Liknaw Yirsaw for editing and commenting the manuscript.

\section{Author contributions}

Conceptualization: ASA, GFW, NBM. Formal analysis: ASA, NBM. Methodology and software: ASA, GFW, NBM. Writing-original draft: ASA, GFW, NBM. Writing-review \& editing: ASA, GFW.

\section{Competing interests}

The authors declare no competing interests.

\section{Ethical approval}

Before going to the field work for data collection, ethical clearance was obtained from College of Social Sciences and Humanities Research, Community Service and postgraduate coordinator of Debre Markos University with approval number "CRCP-33-0811 ". An official letter that requests the support of concerned bodies was written from the office of College of Social Sciences and Humanities Research and Community Service of Debre Markos University to provincial and District administrations after the research project was approved. Then official permissions were obtained from provincial and district level rural land Administration and Use offices of Jabi Tehnan and Ayehu Guagusa districts. Throughout the completion of the study, the research was undertaken in accordance with relevant ethical guidelines, and the study participants were fully informed about the purpose of the research and data management.

\section{Informed consent}

Verbal informed consent was obtained from respondents and participants with the assurance that the information gained kept confidential and used only for the research purpose.

\section{Additional information}

Correspondence and requests for materials should be addressed to Asabu Sewenet Alamineh.

Reprints and permission information is available at http://www.nature.com/reprints

Publisher's note Springer Nature remains neutral with regard to jurisdictional claims in published maps and institutional affiliations. 
(c) (i) Open Access This article is licensed under a Creative Commons Attribution 4.0 International License, which permits use, sharing, adaptation, distribution and reproduction in any medium or format, as long as you give appropriate credit to the original author(s) and the source, provide a link to the Creative Commons license, and indicate if changes were made. The images or other third party material in this article are included in the article's Creative Commons license, unless indicated otherwise in a credit line to the material. If material is not included in the article's Creative Commons license and your intended use is not permitted by statutory regulation or exceeds the permitted use, you will need to obtain permission directly from the copyright holder. To view a copy of this license, visit http://creativecommons.org/ licenses/by/4.0/.

(C) The Author(s) 2021 